\title{
Minha campanha para o Collège de France ${ }^{1}$
}

Maurice Halbwachs ${ }^{1}$

\section{Documento}

Palavras-chave: memória, história das

ciências, biografia.
Key words: memory, science history,

biography. 
Eu me havia proposto escrever, como Loisy, a história de minha campanha para o Collège de France. Eis aqui, aconteça o que acontecer, estas poucas notas retrospectivas, como memento.

Há cerca de dez meses, pensei que a cátedra deixada vaga pela suspensão de Mauss (por ser judeu) seria talvez provida um dia. Um movimento instintivo ... E decidi ir ver Faral, o administrador do Collège. Eu havia feito com ele, Gilson, Strowski, o padre Chenu, a travessia do Havre a New York no De Grasse da C[ompagn]ie Transatlantique, em setembro de 1930, e durante esses oito ou dez dias nós estivemos ligados. De retorno, eu o havia visto em New York. Ele me havia convidado a almoçar em seu clube, e a passear na universidade de Columbia. Cinqüenta anos, mas de aspecto muito jovem, olhos azuis, porte de um oficial de marinha. Aluno de Bédier, graças a seu mestre foi nomeado muito cedo para o Collège. Excelente administrador, dizem. Trabalhador honesto (a literatura da idade média, Villehardouin, etc.), mas inexpressivo. Divertiu-me um dia a respeito de De Grasse, porque ele se enfurecia contra Gustave Cohen, e o qualificava como "poltrão" e "imbecil" (em presença de Gilson bastante escandalizado). Anticlerical, muito fiel à lembrança de Lucien Herr - o que nos aproximava. Protestante ( o que eu ignorava então). Yvonne conheceu sua mulher em Sévigné. Havia sido meu aluno, quando fiz meu estágio no Henri IV. Fui então vê-lo. Acolhida muito cordial. Ele pensa que a questão da idade não tem grande importância: "isso depende da pessoa". Mas, atualmente, a regra é que não se proveja (durante a guerra) senão a metade das cátedras vagas. A de Mauss foi reservada. Mas daqui a um ano, um ano e meio, a questão poderá ser novamente colocada . Ele me exorta a falar desde já a meus amigos. Seria melhor substituir: sociologia (assim se chamava a cátedra de Mauss, sucessor de Izoulet) por um outro título. Eu sugiro: psicologia coletiva. Que seja. Quem fará a proposição? Sugiro Piéron. Ele concorda. Falamos da guerra, da situação geral. Ele está muito pessimista e desgostoso. O que lhe parece necessário, no futuro, é fazer dos francezinhos técnicos. Por que depreciar a inteligência? É por ela, colocada a serviço da ação, que nós poderemos nos reerguer. E não pelos campos de juventude e outras formações que rebaixam o nível mental. Ao me levar à saída, como falamos de Fèbvre, ele me diz: não conte com ele. Ele quer a todo custo fazer entrar Renaudet.

Em suma, Faral, àquela data (talvez abril de 1942) encorajou-me claramente. Eu o acho, por outro lado, muito amargurado, um pouco deprimido, descontente dos homens e das coisas. Nesses doze anos ele quase não mudou fisicamente. Mas o espírito tornou-se um pouco mesquinho, e o caráter se entristeceu. Casado (bem antes do momento de nossa viagem) com a senhorita [lacuna], bas- 
tante bonita, diretora de uma Escola primária superior (é lá que eles moravam). $[\cdots]$

PIÉRON

No mês de outubro de 1942, Mauss atingia a idade da aposentadoria, tanto que se podia a partir daí falar sem escrúpulo em substituí-lo. Foi nesse momento

que escrevi a Henri Piéron, para lhe dizer minha intenção de me apresentar, caso se colocasse a questão. Ele me respondeu logo que estava completamente a favor da criação de uma cátedra de psicologia coletiva, e que eu podia contar inteiramente com ele. Piéron é um amigo de infância. Nossas famílias eram íntimas. Seu pai, inspetor geral de matemáticas, era ligado há muito tempo com o meu. Eles haviam perdido um filho mais velho, Paul, que era mais ou menos da minha idade. Foi em casa deles (esquina da rua Gay-Lussac e da rua Soufflot) que em 1885 nós vimos, do quinto andar, o enterro de Victor Hugo. Pelos Piéron também conhecemos os Barrère, e sua filha, que foi minha primeira mulher. Henri preparou a agregação ao mesmo tempo que eu. Fui recebido nela antes dele. Mas ele se colocou logo em seguida na psicologia científica, e foi nomeado cedo ao Collège: cátedra de psicologia das sensações. É o tipo de erudito, experimentador tenaz, capaz de fazer descobertas, - com posições definidas e alguma estreiteza (por reação contra a psicologia metafísica). Caráter desconfiado, suscetível, mas com muita afetividade e fidelidade. Escrevi ao mesmo tempo a Mario Roques. Não me respondeu. Mas a carta, em suma, não pedia resposta imediata.

\section{TONNELAT}

No início de novembro, vou ver Ernest Tonnelat. É meu antigo colega da École normale, com quem não cessei de estar em relações de estreita amizade. Desde junho de 1940 ele estava em Lyon. Os alemães censuravam-lhe suas atividades no serviço de informação durante a guerra. Desde então, em 1914-1918, ele havia organizado com Hansi, o caricaturista alsaciano, o serviço de propaganda por panfletos (que os aviões deixavam cair). Eu almoçava então com ele uma vez por mês (certa vez, foi com Hansi). Fazia já alguns anos que ele havia sucedido Andler no Collège, na cátedra de línguas e literaturas de origem germânica. Mas ele havia sido convidado a deixar Paris desde a Ocupação. Vivia em Lyon num pequeno apartamento bem medíocre, avenida Waldeck Rousseau. Eu o havia visto ali em 1941, durante estada para o concurso de Sèvres, e certa vez ele me havia trazido Louis Aubert, que estava de passagem. Em agosto de 1942, como eu fazia o mesmo concurso em Lyon, ele veio me ver na Faculdade. Disse-me que sua mulher estava num estado desesperado (ela morreu quinze dias 
depois). Ele havia obtido garantias de que lhe permitiam retornar a Paris. Vou então vê-lo, no boulevard Jourdan 95 (Cidade universitária), e faço alusão, ao deixá-lo, à eventualidade de minha candidatura. Ele me diz logo que isso o interessava muito, pois a regra que prescrevia o provimento de apenas metade das cátedras acaba, parece, de ser revogada, e a de Mauss será seguramente provida. Aconselha-me a ir ver logo as pessoas que eu conheço, pois haverá uma reunião no final de novembro, na qual se falará desse assunto, bem como de outros. Quando, em 1935, eu sonhava em me apresentar à sucessão de Mauss (cátedra de história do trabalho), ele havia se surpreendido e decepcionado muito de me ver renunciar a ela. Mas foi ele quem, sem o saber, me havia desencorajado ao me dizer: Bédier afirma que você não tem nenhuma chance. No fundo, Bédier se enganava, e eu acredito que teria sido eleito. Mas não havia então diferença entre a Sorbonne e o Collège quanto ao limite de idade (enquanto, agora, é de 67 anos na Sorbonne e 70 anos no Collège). Eu acabava de ser nomeado na Sorbonne e não previa que teria ali tanto trabalho e não poderia fazer outra coisa além disso.

Tonnelat é um bom rapaz, cuja maior qualidade é a modéstia, uma modéstia natural e simples, que não é nem um pouco como em muitas pessoas, o manto do orgulho, mas traduz o sentimento justo de faculdades médias. Nascido em Orléans, um pouco terno, ele havia reencontrado Péguy, seu antigo companheiro desse lugar, e Péguy o encontrava no Luxembourg para lhe explicar como eles fundariam a cidade do futuro ... O que o perturbava muito.

\section{GILSON}

Visitas, portanto, às "pessoas que conheço". Primeiro, Étienne Gilson, professor de História da filosofia da idade-média. Minhas relações com Gilson remontam a Poitiers onde nos encontramos para os bachalerados, ele vindo de Rochefort, e eu de Tours. Visitamos juntos as igrejas romanas. Católico praticante, ele estava então em plena simpatia com o movimento modernista, e muito encolerizado contra o papa que lhe havia barrado o caminho, eliminando os modernistas de todos os seminários. Ele se expandia também em tiradas um pouco ridículas sobre a imoralidade que reinava nos meios marítimos de Rochefort. Nomeado em Tours para me substituir enquanto eu estava na Alemanha (19101911), recém-casado, ele havia comprado uma casa. Meu retorno o constrange muito: ele conseguiu se fazer nomear em Angers, e dava ali seus cursos, mas morava em Tours. Nós nos víamos às vezes (eu não estava casado ainda). Ele gostava de música, não tocava, mas lia com virtuosismo. Gilson era de um família muito modesta: pequeno alfaiate, confeccionista, do subúrbio, - família com muitos filhos. Encaminhado pelos vigários: catecismo de perseverança, cantando nos coros de igreja, etc. Desse modo, muito temperamento, um garoto parisiense in- 
solente, e muita ambição. Ele preparava, em Tours, sua tese sobre a vontade em Descartes, enquanto eu me ocupava da minha: a classe operária e os níveis de vida. Estávamos aos antípodas, pois, em Descartes, o que o interessava, era a influência exercida sobre ele (pensava Gilson) pela filosofia medieval. Quanto ao sábio, ao filósofo científico, ao Descartes voltado para a ciência moderna, ele pouco se preocupava. Ignorava até os elementos de matemáticas. Defendemos nossas teses quase ao mesmo tempo, em 1912. Ele foi nomeado mestre de conferências em Lille à véspera da guerra (contra mim). Encontrei-o em seguida na Universidade de Strasbourg, que ele deixou bastante cedo pela Sorbonne. Relações amistosas em Strasbourg, amistosas é talvez excessivo, pois eu sentia nele alguma frieza, senão hostilidade. Nos aproximamos quando estive com ele na América, em 1930. Eu me lembro de que, no navio, após uma conversação comum em que eu havia contado que assistia outrora, em Notre-Dame, aos sermões do padre Olivier, ele me chamou de lado, e quase inquirindo, perguntoume brutalmente por que, sendo católico praticante outrora, eu havia mudado para a descrença. Mas foi muito gentil e prestativo quando chegamos a New York, explicando-me a América, e muito interessado em minhas reações. Voltamos juntos, sozinhos, em segunda classe, no Paris. Depois nos perdemos de vista. Eu sabia que ele militava junto aos Dominicanos, que pedia para os católicos não somente escolas próprias, mas quase, a possibilidade de viverem separados dos não-católicos todo o curso de suas vidas, em suma, a imigração para o interior... Quando nós íamos para a América, Mauss havia sido nomeado para o Collège, contra Chevalier, por um voto de diferença. Seis meses antes, Mauss e Chevalier haviam tido o mesmo número de votos. Gilson, que havia querido se apresentar, havia se retirado antes, creio, em todo caso, após o primeiro turno. Ele foi nomeado na sucessão de Picavet pouco tempo depois. Um de seus irmãos é vigário em Paris.

Vou então vê-lo uma manhã, na avenida Émile Acollas 2 (ao lado do Champ de Mars), no primeiro andar. Ele vem me pegar na antecâmara, e me diz logo em seguida que eu flutuo nas minhas roupas "porque o senhor não se empanturra $\mathrm{o}$ suficiente". Ele está amarelo e muito flappi. Objeta logo a seguir minha idade. Pradines fracassou por esta razão, todavia contra Lavelle (cuja candidatura ele combateu outrora em Strasbourg, e ainda desta vez). "Agora, diz ele num tom rancoroso, eles tem Lavelle - e vêem o que é". Por outro lado teme, por mim, que os historiadores não queiram uma cátedra de filosofia nova (psicologia coletiva ...). Seria preciso um outro título, com a palavra: história. Falamos da situação geral. Ele está muito amargo. Perseguem-se os católicos, nos campos, os professores primários continuam ... E isso sob o regime de Pétain! Respondo que me parece pelo contrário haver aproximação contra o inimigo comum. Ele não 
crê em nada disso. Zomba de "Bonnardi". Muito resistente'2, inflama-se contra os campos de juventude. A grande confiança na América. Quando nos separamos, diz, após uma hesitação: “ apesar de tudo, vamos acabar talvez nos entendendo sobre seu nome".

\section{PigANIOL}

Visito em casa Piganiol, professor de civilização romana. Nomeado há um ano, da Sorbonne ao Collège, como sucessor de meu velho colega Albertini. Conheci-o bem em Strasbourg, e creio que ele tinha por mim (como eu por ele) muita simpatia intelectual. Enviava-me todos os seus livros, e conversávamos amiúde e longamente. Ele morava muito perto de nós, em Strasbourg, num pequenino apartamento. Seu filho estava com os nossos no liceu. Pequeno auvergnat $^{3}$ medíocre (o encontrávamos na Orangerie, estranhamente suspenso ao braço de sua mulher). Carcopino não gostava dele; $\mathrm{C}$ [arcopino] tinha muito mais talento que $\mathrm{P}$ [iganiol] mas $\mathrm{P}$ [iganiol] era muito melhor historiador, historiador de raça, capaz de fazer descobertas. Ele reside na rua da Nuée Verte 40 (perto da porta de Montrouge). Recebe-me muito amigavelmente, diz que serei um ganho para o Collège, compromete-me a fazer rapidamente minhas visitas, antes do fim de novembro. Excesso de amabilidade talvez. Não me sinto seguro de que

30 votará em mim (eu era, é verdade, um pouco desafiante demais). A carta que ele me escreveu quando lhe enviei minha Topographie légendaire testemunhava, além da estima, uma adesão total à minha tese e ao meu método. 
FEBVRE, 28 DE OUTUBRO

Lucien Febvre, professor de história da civilização moderna, rua do Val de Grâce, no $4^{\circ}$ andar. Velho companheiro, amigo de sempre, mas sobretudo desde Strasbourg onde as relações entre nós, entre nossas duas famílias foram estreitas. Estamos além disso do mesmo lado. Eu colaborei largamente nos Annales d'histoire économique et sociale. Ele me pediu uma grande contribuição à Enciclopédia francesa, volume III, a espécie humana (do ponto de vista do número ... Toda a demografia que retomei, com Sauvy e Ulmer como colaboradores. Mas eu dei a maior parte).

Rapaz singular. Muito inteligente, cheio de um talento generoso; muito temperamental, que dá por vezes a impressão de autoridade; de espírito, de estro. Entre os historiadores se sobressai por um modo pessoal e muito vivo de renovar as idéias, por uma grande largueza de visão. Mas todas essas qualidades são estragadas por um amor-próprio doentio, desconfiado, agressivo, por uma vaidade que chega à megalomania. "Ele havia aprendido, lê-se em Zadig, capítulo I, no primeiro livro de Zoroastro, que o amor-próprio é um balão inflado de vento, de onde saem as tempestades quando se faz ali uma picada."

Lucien Herr não gostava de Febvre. Achava-o muito empolado, lisonjeiro, ofensivo por sua autoconfiança. Escolhido por de Monzie para ser o Diretor da Enciclopédia francesa, ele se considerava uma sumidade. Entrou no Collège à força, tendo se obstinado, e se apresentado três vezes, creio. Desde então, nada conta mais para Febvre e sua "coterie", entenda-se um grupo de pessoas que ele conheceu outrora das quais se rodeou, com as quais jurou (porque ele e eles são homens de gênio) conquistar os postos de comando na Universidade e no mundo intelectual. Junte-se um traço que não me agrada muito nele, que se deve talvez a obscuras origens camponesas: a dureza com os velhos, as pessoas que a idade ou a doença tornam menos resistentes. Quando Blondel, que era no entanto de sua coterie, um de seus mais velhos amigos, se apresentou ao Collège, ele falava a respeito num tom de piedade depreciativa: "Quando ele fazia suas visitas, acreditava-se ver um ancião.” Pisoteou Seignobos, Bouglé, com muito mau gosto (apesar de eu tê-lo defendido contra meu sogro, quanto a seu artigo necrológico sobre Bouglé. É preciso que eu faça meu mea culpa; era meu sogro quem tinha razão).

Vou então à casa dele, sabendo no entanto que ele queria fazer entrar Renaudet no Collège, e não me iludia, - mas para colocá-lo logo em face de minha resolução. Ou seja, ele queria propor Renaudet como sucessor de Valéry. Isto foi prolongado por um ano. Renaudet poderia esperar até lá. Devo dizer que anteriormente, quando fingi me apresentar ao Collège, Febvre não me encorajou. $\mathrm{Pa}$ ra a sucessão de Simiand, ele estava decidido a votar em Dolléans (talvez por re- 
comendação de De Monzie). Conversação cordial. Objeção sobre a idade. Mas, em suma, parece aceitar esse fato que o pega de improviso. A senhora Febvre chega, e conversamos de outra coisa. Entretanto Febvre aparenta ruminar; remexe pensamentos mal definidos, parece um touro, seus olhos saltados, um pouco vermelhos, sua face se congestiona. Quando nos separamos, diz que falarão disso à sua volta, que se informará. Enfim, não se recusa a encarar minha candidatura. Mas nenhuma palavra para me dizer que estará comigo. É um pouco o que eu esperava, e talvez mais. Pois não me opôs Renaudet. Devo mesmo dizer que minha impressão, ao sair, era de que ele, pelo contrário, estaria do meu lado.

Eu me iludia. Tonnelat me dizia alguns dias depois, que ao longo de uma reunião havia-se falado da cátedra de Mauss, e que ele havia ouvido Febvre falar de mim com Robert, o epigrafista. Foi então, ou um pouco mais tarde, que tendo falado com Febvre, encontrou-o bastante evasivo ao que me concerne: "Ele gosta de você. Mas está preocupado com Renaudet." "Na mesma reunião, ouviu Hazard falar a Siegfried de Le Bras como sucessor possível de Mauss, recomendando-o. Isso me aborrrece. Le Bras, professor de direito canônico na Faculdade de Direito, Diretor nos Hautes Études, é uma personalidade. Estou muito bem com ele. Ele fez tempos atrás uma excelente comunicação no Institut français de sociologie sobre as estatísticas de católicos praticantes na França, que lhe pedi para os Annales. Ele é inteiramente do nosso grupo. É alguém muito jovem ainda, cheio de temperamento, para impedir que não se nomeie honorário Le Fur, esse jesuíta disfarçado, colaboracionista. Se Le Bras se apresentasse, certamente teria chances.

\section{RoQues, 25 DE NOVEMBRO}

Minha visita seguinte foi à casa de Mario Roques, membro do Institut, professor de história do vocabulário francês no Collège, onde sucedeu a Bédier. Roques é um velho companheiro do Henri IV: ele era veterano, eu, calouro. Reencontrei-o no ministério de Armamento, onde ele era diretor do gabinete de Albert Thomas com Simiand. Nesses últimos anos, nos vimos freqüentemente, em $\mathrm{Pa}$ ris ou em Lyon, no concurso de Sèvres (ele presidia a banca). Capacidade de trabalho extraordinária. Atividade organizadora. Grande firmeza. Conhecia bem os homens, hábil, paciente, manipulador. Com tudo isso, era porém brusco, desagradável, brutal, até o carrancismo. Nada fácil aos que não o conhecem. Não é sem inquietação que vou vê-lo, apesar de nos tratarmos por tu e de termos muitas lembranças e amigos comuns. Ele é além disso muito influente, mas não se compromete numa questão senão com conhecimento de causa. Mora na rua de Poissy 2, numa velha casa que deve datar do século XVII, com uma larga escada e vastos cômodos. À entrada, em volta de uma grande mesa, dois secretários, um 
rapaz, uma moça com óculos, compulsam os dossiês. Encontro Roques enfurnado num pequeno gabinete de trabalho, de roupão: de lá tem-se uma vista magnífica sobre os cais, sobre a catedral. Moro aqui há quarenta anos, me diz ele (é membro da sociedade do Velho Paris). A conversação se estabelece logo de início num tom de cordialidade quase afetuosa. Ele devaneia logo em seguida sobre os votos e meios, e passa em revista a maior parte dos professores do Collège, caracterizando cada um de um modo divertido e muito seguro. "Baruzzi. Doente de vaidade. Veja-o logo, de modo que ele tenha tempo de mudar de opinião seis ou sete vezes. Piéron, desconfiado, inquieto, se perguntando se falou demais, ou de menos. Robert, temperamento insaciável de tuberculoso.” Etc. Crê que Faral votará em mim. Grandes reticências quanto a Febvre. Pergunta se conheço Hazard, Valéry, Joliot. Me recomenda ver Chassigneux que é um antigo colega do Henri IV, e fiel a ele, creio. Mas, antes, a seção de ciências filosóficas e sociológicas, sobretudo Siegfried, Massignon, Coornaert. "E, também, Pelliot, pois, se ele nos dissesse que há um orientalista...." Pelliot falará a outros a respeito. Leriche também seduz um outro biologista. Quando lhe digo o que soube sobre Le Bras e sua possível candidatura: "Ah! Isso seria muito aborrecido. Nesse caso, procure-o, e escolham entre um e outro.” Acrescenta que não se deve perder tempo, porque há pessoas que se antecipam, em particular Dauzat, o lingüista dos Hautes Études. Me deixa ouvir que está do meu lado, e pede para mantê-

lo informado. "Falarei às pessoas do Institut quinta-feira" Eu saio, mais leve. Se tenho Roques do meu lado, é um grande ponto.

\section{COORNAERT}

Coornaert é professor de história do trabalho. Sucedeu a Simiand. Eu lhe disse que poderia ser nomeado para essa cátedra. Se não for, Maxime Leroy poderia passar. Coornaert é um medíocre. Marc Bloch, batido por ele nos Hautes Études, custou a crer. Ele fez algumas pesquisas eruditas sobre as corporações no século XV. Encontrei-o numa tarde à saída de seu curso nos Hautes Études, e descemos pela galeria Richelieu. Era a primeira vez que eu o via. Tem um forte sotaque belga, aliás nada de característico. Democrata-cristão, e atualmente muito resistente, - mas bom católico, e defendendo a subvenção das escolas livres. Nada de especial na nossa conversação (sobretudo sou eu quem fala). Ele me diz somente que será necessário que eu consiga Febvre, o que me deixa supor que o seguirá.

\section{Pelliot}

Encontro marcado por telefone com Pelliot. Vou vê-lo pela manhã. No museu de Ennery, avenida do Marechal Foch 59 (outrora do Bois de Boulogne, bem 
ao lado da rua Picot, onde morei em 1903-1907, quando de meu primeiro casamento). Subo dois andares e preciso esperar um pouco antes que Pelliot venha abrir. Paul Pelliot, membro do Institut, professor de línguas, história e arqueologia da Ásia Central. Explorador famoso que trouxe de lá coisas belíssimas que se vêem em parte no museu Guimet. É um nababo, loreno, creio, com a postura rude e franca das pessoas de Nancy. Está todo constipado, com gorro e lenço no pescoço, tossindo como se fosse entregar a alma. De saída, diz que não concorda que se admitam no Collège pessoas idosas. "Isso não deu certo." Ele mesmo entrou com 35 anos, e ali está há 30 anos. Como pareço um pouco desconcertado, acrescenta, corrigindo-se: "Mas há outros fatores que poderão atuar a seu favor." E lembra que se havia falado muito de mim para suceder Simiand. Digolhe algumas palavras sobre meus trabalhos, e falamos de outra coisa: "Tem notícias de Mauss? Que dizia o rádio ontem à noite?” Digo-lhe que tive por amigo de infância Robert Gauthiot, e que Madame G[authiot] nos levava aos domingos ao museu Guimet. Ele o conheceu bem: G[authiot] estava no coração do Tibete em 1914, quando a guerra foi declarada. Na hora de nos separarmos, faço alusão a seu curso, a suas explorações. Fechada a porta, ele a reabre, para me perguntar: "E esse curso de Labroué? Que infâmia. Uma vez retornada a paz, terei bastante a dizer sobre isso." Qualifico como ela merece essa "imundície", que foi depositada no meio de pessoas, no conjunto, honoráveis. E parto após uma entrevista que não durou mais que meia hora, convencido de que fiz uma visita para constar e acreditando compreender que a questão da idade era para ele decisiva, que ele não votaria em mim.

\section{LERICHE, FIM DE NOVEMBRO}

Vou resumir minha visita a Pelliot porque Leriche me havia encontrado nessa mesma manhã. Leriche é professor de medicina (esse é o título, simples, de sua cátedra, para a qual foi nomeado alguns anos antes da guerra). Grande cirurgião, de reputação mundial. Nós o conhecíamos desde que ele remendou o pulso de meu sogro em 1916-1917. Amigo íntimo dos Montet, Léon Delaroche, do grupo Lyonês, de uma antiga família de Lyon. Quando foi nomeado para a universidade de Strasbourg, e enquanto ali ficamos, nos vimos muito. Ele me tratou quando queimei profundamente a perna e, por volta de 1933, fez uma transfusão de sangue (do sangue de Francis) em Yvonne, que havia tido uma grande hemorragia. Foi em sua casa que conheci Duhamel, no momento em que eu ia partir para a América. Nós todos trabalhamos em sua eleição. É um homenzinho que se assemelha a um garoto, nariz achatado, uma coroa de cabelos esvoaçantes em volta de seu crânio, sobre sua testa bastante desprovida. Tem opiniões sobre tudo, idéias por vezes inesperadas, o espírito sempre trabalhando, gracejos, jogos 
de palavras, o conjunto compondo uma espécie de originalidade. É, além disso, um ás em sua área. Transpõe em experiências as cirurgias que faz. Escreve muito. - Mas, desde 1940, tomou uma atitude oportunista que não nos agradava. A última vez que o vimos (foi em fins de 1940, na Enciclopédia, em presença de Febvre), ele questionou vivamente Yvonne, que atacava Vichy. Colaboracionista? Febvre nos disse que não. Em todo caso, foi colocado à testa da corporação dos médicos: foi ele quem anunciou (em termos além do mais calculados, e com pesar) aos médicos judeus que não teriam mais o direito de clinicar. - Sua mulher é alemã, e ele sofreu por isso na guerra precedente. Não creio que isso explique minimamente sua nova atitude. É um homem inteligente, que procura se adaptar.

É na clínica médico-cirúrgica da rua Jules Guesde, aliás Hospital Léopold Bellan, no XIV [arrondissement, n.t.], perto do cemitério, que eu o encontro, de blusa branca. Pouco mudado, só um pouco pálido e magro, mais pensativo talvez. Ele acolhe muito bem minha candidatura. A idade? É melhor entrar tarde no Collège. Se se chega aí muito depressa, estiola-se em seus hábitos, não se renova mais (ele mesmo aí entrou tarde...). Falamos logo em seguida de outra coisa. Ele faz a apologia do Marechal, que viu seis ou sete vezes (como paciente). "É um ancião magnífico. Atividade intelectual normal, só um pouco diminuída. E além disso, se preocupa sobretudo com os pobres diabos, os prisioneiros, a juventude. Ele tem muito sentimento ....” No entanto, Leriche está em vias de mudar, mudou... "Desde 1940, diz ele, compreendi que os alemães não ganhariam... Isso pode durar ... Não se sabe por quanto tempo... talvez 18 meses (estamos em novembro de 1943). - é logo após a ocupação da África do Norte. Darlan não foi ainda abatido. Segundo Leriche, vê-se bem hoje que Pétain e Darlan levaram uma política destinada a enganar a Alemanha". Acrescenta, hesitando um pouco: "Quanto a Laval, é mais discutível." De resto, acaba de fazer sua demissão de presidente da corporação médica. E o Comitê inteiro fez o mesmo. Deixo-o, feliz de nos sentirmos mais próximos. É toda Strasbourg que reviveu. Eu não diria que o vento muda. Mas que se está disposto a perdoar aos que têm o espírito aberto, e tanta boa vontade...

JOLIOT, 12 DE DEZ[EMBRO]

Joliot é o primeiro cientista do Collège que vou encontrar. Professor de química nuclear, no prédio dos novos laboratórios que se estende para o alto. Aqui ainda, uma excursão no tempo. Vi Joliot e sua mulher Irène Curie há mais ou menos cinco anos, num almoço no ministério das Relações exteriores em honra do psicólogo estatístico Spearmann. Estava-se então em plena guerra da Espanha. Perguntei a Delbos, o Ministro, por que nós havíamos chamado de volta nosso 
embaixador junto aos republicanos. Ele me mandou ao embaixador da Inglaterra, que me respondeu com futilidades, - muito inquieto quanto ao destino de um quadro de Gréco que se encontrava perto de Madri... Havia um grupo com Langevin, Perrin, Joliot-Curie, ao qual me juntei após almoçar. Joliot me havia parecido muito simpático, e nós tivemos uma pequena conversa muito cordial. Nesse momento, Francis trabalhava em seu laboratório, no Institut Henri Poincaré. Irène cuidava dele, em princípio. Mas ela o deixou atolar-se por mais de seis meses. Acompanhei-a até o vestiário, falando-lhe de Francis. A refeição abundante a havia posto em boas disposições, e apesar de parecer taciturna, prodigalizou-me boas palavras, com um ar de bom humor... De passagem, e para marcar dois pontos de história pessoal: $1^{\circ}$ ) Vi uma vez o grande Curie, num enterro, na praça diante da igreja (qual? não sei mais). Foi Henri Piéron quem o identificou, de costas, isolado; ele parecia um primitivo, um antropopiteco silencioso, um pouco bravio, perdido no mundo dos homens civilizados; $2^{\circ}$ ) Vi uma vez, também, a senhora Curie, a grande. Ela atravessava o canteiro onde se construíam os edifícios científicos sobre o lugar do antigo convento (das Ursulinas, creio), e em sua roupas pretas, um pouco curvada, evocava alguma abadessa do século XVII, a madre Angélique, a madre Agnès de Sainte-Croix...

Foi difícil obter um encontro com Joliot e ele me fez esperar muito tempo. 36 Mas em seguida conversamos durante quase uma hora, eu me sentia muito próximo dele. Falamos sobretudo de estatística [nota à margem: equilíbrios entre raposas, coelhos, etc., com inércia nas subidas e descidas da curva, porque tanto os coelhos, como as raposas se reduzem em número. Falei-lhe das observações de Malthus]. Ele me escutava com a atenção de alguém que quer se instruir. Quando lhe dei meu livro sobre a Morphologie sociale, disse-me que o enviaria à sua mulher, que está novamente em Leysin. Sobre Bauer (o cunhado de R[obert] Hertz, físico: ele esteve muito tempo conosco em Strasbourg), ele esboça uma careta. "Muito inteligente, sem dúvida. Mas nenhum resultado. Em escultura, se você dá um toque aqui, e outro lá, não é esse o modo de fazer uma obra." É sobre o cálculo das probabilidades que ele insiste, e lá eu perco um pouco o pé: mas certamente ele não o percebe... Não tocamos nas questões políticas. Ele me pede notícias de Francis. Ao me reconduzir, pergunta se estou em acordo com Mauss sobre minha candidatura. "O ponto de vista sentimental é importante, aqui, para mim.” É um homem jovem, franzino, magricela, um jovem cientista todo inteligência, um pouco diáfano. Contanto que não desmaie. Disseram-me que ele não assistia sempre às reuniões [nota à margem: frágil, delicado, pele branca, traços finos, intelectual, parecido com Wurmser].

BARUZZI 
Jean Baruzzi, professor de história das religiões, praça Victor-Hugo 3 (o que me leva ao meu antigo bairro...). - único que me respondeu pelo correio de volta, e que me recebeu de chinelos... é um fabricante de balões para crianças, balões de ar, sobre os quais está escrito: Saint Leibniz, Saint Jean de la Croix, Saint Paul, etc. Andler (que se enganava muito sobre os homens) fê-lo entrar no Collège, não se sabe porque [...]

De resto, ele me cobriu de flores, e se extasiava, e fazia grandes respirações, pronunciando: a psi-co-lo-giiiaaa-co-le-ti-va, - como é interessante! Tive seu irmão como colega, antigamente. Ele se ocupava com estética. Esnobe bem pensante. Os dois irmãos vivem juntos. Creio que nem um nem outro é casado. Jean Baruzzi sucedeu a Loisy. Trabalha, ou trabalhava então, sobre Lutero.

\section{MASSIGNON}

Massignon (Louis), professor de sociologia e sociografia muçulmanas (Fundação da Argélia, da Tunísia, do Marrocos e de diversas colônias), rua Monsieur 21, perto da rua Babylone e dos Invalides. Um ser incompreensível, diziam-me antigamente - e que eu teria talvez conseguido agarrar... A primeira vez que ouvi falar dele, foi quando eu estava no Egito, em Alexandria, por esse jovem judeu convertido, filho do "barão" de Ménache, com quem conversei longamente (nossa excursão a Aboukir). Muito filósofo, o jovem Ménache me disse então que em Paris seguia sobretudo os cursos de Massignon, e compreendi que por ele se explicava um pouco sua conversão. Eu havia almoçado com ele em casa de seu pai, presidente do grupo sionista: havia no pai, quando olhava o filho, um ar de desgosto misturado à afeição. Mais tarde, o filho ingressou nos Dominicanos. Essa lembrança me transporta a 1927.

Em seguida, mantive alguns contatos científicos com Massignon. Há alguns anos, fui vê-lo nos Hautes Études para falar sobre Constantinopla, onde eu devia ir. Vi-o ainda alguns meses mais tarde, em sua casa. Um pouco incompreensível, de fato, no sentido de que ele não deixa uma pessoa falar, mas lhe expõe o que o preocupa no momento, e que é de resto sempre digno de atenção, - mas é ele quem a envolve, e a pessoa não consegue tomar contato de verdade com um pensamento que adere a ela, mas escorrega sobre ela. Em todo caso, meu estudo sobre a população em Constantinopla criou entre nós como que um elo... Ele é, de resto, muito "resistente", muito pró-ingleses, e se une estreitamente aos católicos como Claudel e Mauriac. Encontrei-o, um dia, transtornado, porque acabava de ver uma judia (estudante) cujo marido havia sido preso pelos alemães. Desta vez, vou vê-lo para lhe falar de minha candidatura. Mas o que posso lhe dizer se perde no que ele me expõe de seu lado, e que concerne a outras cátedras vagas e às intrigas que se relacionam a elas. Tem o gosto pela precisão e insiste nos 
detalhes. Será para evitar de me responder? Ou então, será essa sua maneira habitual? Impressão de que ele quer se preservar, não se pronunciar. Isso não impede que se prolongue um sentimento de cordialidade nascido do fato de que nossos estudos atuais se encontram em alguns pontos. Vejo-o, muitos dias depois, numa galeria da Sorbonne, bem cedo, de manhã. Ele come disfarçadamente um pedaço de pão. Bruscamente, pede notícias de meu sogro. É que eles se encontraram durante a guerra da Espanha, com André Gide e Langevin. Tratava-se de ir a Madri de avião. Mas todos se furtaram, exceto meu sogro. "Ele foi sozinho, me diz Massignon sorrindo." "Sim, acrescento, ele é muito corajoso"...

\section{A [NDRÉ] MAZON, 5 DE DEZEMBRO}

André Mazon, professor de línguas e literaturas eslavas... Nós havíamos estado em bons termos, em Strasbourg, onde ele ficou bastante tempo. Convidoume para jantar uma noite com Benès, o ministro das Relações exteriores da Tchecoslováquia, num grupo pequeno, com Pfister e Vermeil e, mais tarde, em Paris, outro jantar com d' Oldenburg, o Presidente da Academia russa, aristocrata aliado do bolchevismo, membro do soviet de Leningrado. Mazon, apesar de ter estado prisioneiro por algumas semanas quando da revolução russa, permaneceu muito objetivo. De resto, suas simpatias pelo mundo eslavo o colocavam de saí-

da num ponto de vista amplo e progressista. Atualmente está entusiasmado com os tchecos. Mas, por outro lado, antigo aluno de Stanislas, tem maneiras um pouco clericais. Existe nele um não sei que de fugidio, em certos momentos a aspereza e a dissimulação de um jesuíta, o gosto, creio, das pequenas coteries e das pequenas intrigas. Um dissimulado, sorridente, diga-se, e capaz de movimentos generosos, quando eles estão na linha de sua eslavofilia. É assim que, quando fui vê-lo para lhe falar de minha candidatura, não o tendo encontrado da primeira vez - disse-me que havia estado no campo, perto de Issoudun, creio, porque eles cuidavam em sua casa da filhinha de um judeu russo (um intelectual, seu antigo aluno ou um amigo) que havia sido preso pelos alemães. Ele tomou o trem e atravessou a linha para colocar a garota entre as mãos da avó, e foi com uma emoção profunda que contava como ela morreu quinze dias depois. [nota à margem: Um judeu russo. Golovine, um de seus melhores alunos, que ele havia feito nomear em New Cambridge, na América, mas que havia sido preso no momento de partir. A senhora Mazon conduziu a mãe a um vau do Cher que conhecia, e que ela pôde atravessar para passar à zona livre. Por 3 meses cuidaram da menina (4 anos), depois Mazon levou-a e devolveu-a à sua mãe em Cantal. Ela morreu dez dias depois]. Em suma, contraste muito surpreendente entre uma inteligência mobiliada de noções modernas, aberta às idéias estrangeiras, e um caráter muito mesquinho e pouco franco, entre uma sensibilidade real e uma secura de 
intrigante (é talvez ainda mais complicado, pois me parece que de fato ele aparenta ser intrigante, porque isso lhe dá um sentimento secreto de superioridade). É preciso levar em conta por outro lado a educação, as tradições de família. Seu irmão, Paul Mazon, excelente helenista, fino, cheio de talento literário do melhor quilate, é ao mesmo tempo um reacionário fervoroso.

Fui vê-lo sem me iludir. A primeira vez que cogitei do Collège (quando Mauss se apresentou), ele já estava ali, e eu lhe havia escrito. Respondeu-me que havia, antes de minha carta, recebido um telefonema de Gilson, dizendo que a vaga lhe interessava. Ele teria no entanto desejado que eu me apresentasse para que Mauss perdesse os votos que eu teria. Porém, hipnotizado por Gilson, ficava de seu lado. Quando cogitei à sucessão de Simiand, Mazon esteve longe de me encorajar. Desagradava-lhe, visivelmente, que eu entrasse no Collège.

Desta vez, quando lhe anunciei que me apresentava, esteve mais esquivo que nunca, como se o que eu lhe expunha não lhe dissesse respeito, e não provocava de sua parte nenhuma reação. Simplesmente, passou a outro assunto. Não insisti.

Minha mulher gostava muito da senhora Mazon, em quem encontrava muita graça. A senhora Mazon escrevia contos, contos sobre vagalume e outros mais, e encontrava em Yvonne uma leitora cheia de simpatia. Ela tinha originalidade, imaginação, uma certa veia provinciana. Era bem mais natural que seu marido, que nos parecia encolhido e afetado. Nunca encontrei alguém que apresentasse nesse grau uma cara dupla, um desdobramento total, como se vivesse em dois planos. Envelhecido antes da idade, curvado, um pouco rançoso. Se insisto nesse ponto sobre sua personalidade, é que eu tenho um pouco de raiva por ele ter-me muitas vezes levado por sua atitude a falar-lhe de coração aberto, e eu percebia em seguida que tudo aquilo havia caído num abismo de indiferença, e talvez de hostilidade.

\section{LAVELLE}

O caso de Lavelle é mais simples. Louis Lavelle, professor de filosofia, que sucedeu Édouard Leroy no Collège, o qual havia sido sucessor de Bergson: dupla queda, e a segunda (o que não se acreditava verdadeiramente possível), mais pesada e mais profunda que a primeira. Quando, professor do liceu Fustel de Coulanges, em Strasbourg, apresentou-se à Universidade, Gilson the barrou brutalmente o caminho. Saindo Gilson, ele se reapresenta e fui eu, então, quem fez um relatório contra ele. Teve no entanto a maioria, de um voto, e ia ser nomeado quando Guéroult, que se havia feito nomear num colégio (por causa de neurastenia) retomou seu lugar. Metafísico tagarela. Mistura de Hamelin e de Bergson sem nada de pessoal. Palavras, palavras, um fluxo límpido que escorreu durante 
muito tempo nas colunas do Temps, e que impressionava os profanos (a senhora Terroine por exemplo...). Quando uma disciplina cai das mãos dos "doutores" para as dos "literatos", é um sinal de que está em declínio. Fora isso, Lavelle é um rapaz simpático, doce, distinto, amável, um pouco insípido. Mas que pensamento grotesco, se se pode mesmo chamar a isso de pensamento...

Quando subo ao $5^{\circ}$ andar da grande casa um pouco triste onde ele mora, rua Paillet 3 (rua que se inicia na rua Soufflot, à direita subindo em direção ao Panthéon), sou recebido por uma empregada que não quer de início me dar seu número de telefone. Uma moça aparece, com o jeito de uma religiosa de olhos tristes. É sua filha, que teve, creio, um prêmio no concurso geral de filosofia. Diz que eu poderia ver seu pai desde que lhe telefonasse. [...] Vejo Lavelle uma manhã, num pequeno escritório escondido que ele tem no térreo. Ele me conta que, estando em Bordeaux em junho de 1940, foi feito Diretor de gabinete por Rivaud, e mantido no mesmo posto por Miraut, que havia conhecido no Temps. Ele hesitou em se apresentar ao Collège, porque temia uma derrota. Na realidade, se foi nomeado contra Pradines, foi devido à situação oficial que acabava de ocupar. [...] Lavelle professa um espiritualismo moral bem pobre, bem pouco original. Visita puramente formal. Certamente não votará em mim.

GRENIER

Subo à casa de Grenier (Albert) que sucedeu Jullian, cátedra de antiguidades nacionais. Um loreno, muito resistente. Velho amigo de Strasbourg. Casado com uma judia (senhorita Dalsace), da qual é viúvo há alguns anos. Seu filho François, atualmente magistrado, gostava muito de Francis, que encontrava nos Éclaireurs (escotismo...). Grenier é culto, muito forte em seu terreno, um pouco acabado, escondendo, creio, muito de humanidade, uma natureza afetuosa e fiel, sob uma casca um pouco rude, um bom rapaz. Ele sai comigo. Nos separamos diante do metrô. Ele me aperta a mão com calor e me diz: "meu caro amigo, pode contar comigo." Sei além disso que ele não gosta de Febvre. Este o combateu quando ele se apresentou ao Collège. Foi em 1934. A eleição teve que ser adiada porque no dia da votação, Matignon, o químico, morreu de repente, na hora em que falava por Grenier.

\section{ROBERT, 4 DE DEZEMBRO}

Louis Robert, professor de epigrafia e de antigüidades gregas. É um ás. Dizse que é um gênio em epigrafia. O mais novo do Collège. Promoção de 1924 à École: ele não tem 40 anos. Eu o havia encontrado em casa de Roussel. Vou esperá-lo à saída de seu curso. Muito robusto, maciço, o corpo muito pesado para 
as pernas, um olhar um pouco inquieto, que se crava, investiga, transpassa. Pessoa obstinada, teimosa; assim que ele fala, sente-se uma personalidade muito forte, um fundo de paixão, uma necessidade de posições firmes. Roussel o considerava, quanto à guerra, excessivamente otimista. Chegamos lá bem depressa. Muito resistente, de fato. Amigo íntimo de Seyrig, que vi na École de Athènes; de uma família de ricos industriais protestantes mulhousianos. Encontrei-o, esse Seyrig, em 1939 durante a guerra, em Beirute, onde ele havia sucedido Virolaud como Diretor de antiguidades. Aliou-se aos ingleses, está agora em Washington. Robert me fala também de Déat, confirma o que me haviam dito, que era ele quem dirigia esse pequeno grupo de alunos de liceu, de que tratam os Os moedeiros falsos de Gide. Eles tinham um revólver, e tiraram a sorte para designar um deles que devia queimar o cérebro em aula, diante do professor, o que de fato foi feito. Déat tinha isso na sua consciência. Sua atitude atual se explica também por sua mulher. Como assinalo sobre Seyrig, que deve ser interessante estar na América neste momento, ele declara que mais ainda é conhecer nossas provações, testemunhá-las e delas participar. Pede-me que lhe envie alguns de meus trabalhos, em particular a Topographie légendaire des Évangiles en Terre Sainte. Eu não sabia, mas soube em seguida que ele era democrata-cristão. É alguém que eu gostaria de ter do meu lado. Mas ele está muito imbuído do espírito dos Hautes Études (l'École des...), e acho que votará em Renaudet.

HAZARD, 5 DE DEZEMBRO

Paul Hazard, professor de história de literaturas comparadas da Europa meridional e da América Latina, da Academia francesa. Discípulo preferido de Joseph Bédier que lhe havia arranjado essa cátedra: na verdade ele simplesmente dá cursos de literatura francesa, num quadro muito clássico, com um pouco de fantasia. É “um brincalhão", diz Mauss... Antigo colega: nos tratamos por tu: mas o conheço pouquíssimo, nunca o frequentei. Quando eu era professor no liceu de Reims, ouvi falar muito dele. Havia deixado atrás de si uma esteira brilhante. Muito hábil, "sabe nadar." Teve grandes ambições literárias, e sofre de não ser (tendo publicado alguns romances) conhecido como grande escritor. Pouco consciencioso, de resto. Reacionário dissimulado, por arrivismo. Em Strasbourg ele fez, uma tarde (quando estava ainda na Sorbonne), uma conferência sobre Stendhal quando procurava abater, ridicularizar e rebaixar seu autor. "Ele viveu, escreveu, amou." Três palavras italianas, sussurradas numa voz untuosa e cantante, três ataques, três recusas de admitir que ele tivesse vivido uma vida feliz, que tivesse escrito obras dignas de durar, que tivesse conhecido as alegrias do amor verdadeiro. Tudo o que havia de clerical em Strasbourg estava ali. Após a 
conferência, conversamos um pouco, em casa de Maugain. Ele disse: "Não gosto de Stendhal."

Rua da Arcade 24, bairro da Madeleine. Um elevador ofegante me leva ao $5^{\circ}$ andar. Grande salão convencional. Uma chaminé monumental onde queima lentamente uma enorme acha. Duas senhoras nada jovens sentadas por ali, como na sala de espera de um médico. Ouve-se a voz de Hazard, e a de uma outra dama, de um timbre agradável mas bem pretensiosa, através da porta. Atmosfera de Academia e de boas obras. Ele reconduz sua interlocutora, entra, me vê, e diz às duas senhoras: "O cavalheiro é professor na Sorbonne, vou fazê-lo passar primeiro, é um privilégio...." Conversamos como dois colegas. Mas eu abrevio. Tenho a impressão, desta vez ainda, que é uma visita puramente formal. Generalidades sobre a guerra, a América, o Oriente. Dos meus livros, ele diz que leu meu Leibniz, do qual se serviu quando escreveu um capítulo sobre o movimento de idéias no início do século XVIII, na literatura Bédier e Hazard. Um homenzinho, e um falso tento. Declaro de resto que esse julgamento que faço aqui é quase inteiramente tendencioso e a priori, que não conheço por experiência pessoal e contato direto nem a inteligência nem o caráter de Hazard. Mas há em seu caso muito arrivismo despreocupado e cínico: ele me parece o superintendente intelectual de um mundo sem grandeza, de círculos decompostos, do que há de mais caduco na burguesia decadente. Isso, com uma certa tristeza aborrecida e desabusada que o tornava um pouco simpático.

\section{SiEGFRIED, 3 DE DEZEMBRO}

André Siegfried, professor de geografia econômica e política. Filho de um senador do Sena inferior. Família protestante de grandes industriais mulhousianos. Diretor da Escola livre de ciências políticas (aprendizes de diplomatas, liberalismo conservador: Rivaud era professor ali). Diretor do Musée Social (mesma tendência). Fez um estudo sério sobre a França do Oeste junto às estatísticas eleitorais, "ilustração de dados estatísticos." Sobretudo, um livro sobre os Estados Unidos, que teve um grande sucesso (li na biblioteca de Chicago, "America goes of age", tradução americana). Albert Thomas, com quem falei em Genève ao voltar da América, me dizia: "decididamente, não é um grande livro." Era também minha opinião. Homem muito derramado, de um talento muito reduzido. Grande burguês, que se derrama em conferências. Conheço-o pouco: alguns encontros acidentais em que só trocamos algumas palavras.

Vou vê-lo na escola da rua Saint-Guillaume onde ele marcou encontro, e me propõe acompanhá-lo à Sorbonne. Vai fazer ali uma conferência para a Liga Colonial, e carrega embaixo do braço grandes mapas enrolados.

Muito amável. Palavra fácil. Expõe claramente, como num conselho de ad- 
ministração; é ele quem fala o tempo todo, e eu não o interrompo. Diz logo que não está seguro de que a cátedra de Mauss seja discutida, e que, no Collège, a tendência seria esperar. Teme-se alguma iniciativa do Ministro, que aproveitaria a ocasião para nomear algum Montandon. Falamos em seguida da América, dos sociólogos americanos, de Middletown, esse livro de Lynd que ele tomou como objeto de seu curso há dois ou três anos. Digo-lhe que li essa obra desde 1930, em Chicago. Ele me cumprimenta por minha obra, diz que me conhece bem, pergunta se é bem no sentido da sociologia americana que me oriento. Dou-lhe algumas precisões sobre o que quero fazer, e lhe dou meu livro: Les cadres sociaux de la mémoire. Essa doação, bem como o que lhe digo de Middletown (de onde resultava que eu conhecia o livro bem antes dele) não foi talvez muito hábil. Essa doação, pois ele não é nada menos que filósofo. Parados diante da Sorbonne, falamos ainda de Vermeil, que é obrigado a se esconder. "De tudo isso, me diz ele, ele terá direito mais tarde a obter reparação. Esses são títulos que não serão esquecidos." Acrescenta: "não posso lhe dizer agora que votarei no senhor, já que fui solicitado por alguém. Em todo caso, eu o prevenirei desde que seja decidido se a cátedra deve ou não ser provida." Tenho a impressão de que votará em Renaudet no primeiro turno. Ou, antes, tive essa impressão mais tarde, e também pensei que ele não votaria, em todo caso, num clerical. É ele quem, por seus trabalhos, se aproxima mais dos sociólogos, apesar de ser muito geógrafo. Enfim, veremos.

Todas essas visitas, eu as havia feito nos quinze dias que precederam a reunião oficiosa da qual me haviam falado. Segundo o que Siegfried acabava de me dizer, eu via que a questão estava muito menos amadurecida do que pensava no início. Também não me surpreendi, no primeiro sábado de janeiro, quando Piéron, na Société de Psychologie (onde eu havia sido nomeado vice-presidente), me diz que de fato o negócio parece adiado. Não se havia falado dele, nessa reunião. No telefone, Mario Roques me confirma que isso poderia ser recolocado, talvez até abril. Mas acrescenta, no tom breve e rouco que é freqüentemente o seu: "continue suas visitas, acabe a série."

No que foi dito acima, queimei algumas datas. É assim que fui ver Joliot somente em 12 de dezembro. Tive que suspender minhas visitas durante mais de um mês. Em 15 de janeiro de 1943 fui ver Chassigneux, antigo colega do Henri IV, professor (há alguns anos) de história da colonização no Collège. Ele passou cinco anos na Indochina. Falamos de Maître (Clodius), nosso antigo colega, normalista, que fez a volta ao mundo, e depois dirigiu ali o Institut des Hautes Études à Hanoï. "Muito inteligente", me diz Chassigneux, "mas que teve afinal uma vida de meio fracassado, tendo-se colocado no chinês muito tarde, sem deixar nada que os eruditos tivessem podido apreciar". Morreu, tuberculoso, há uns 
quinze anos (eu teria muitas coisas a dizer sobre Maître. Mas numa outra ocasião...). Eu revia bem Chassigneux num banco isolado da cagne do Henri IV, barbudo, com mangas de alpaca, exemplo de historiador positivo e um pouco terno. Ele envelheceu muito, é evidente ... Mas é a mesma fisionomia, o mesmo gênero de espírito. Visivelmente tem prazer em me rever. Roques, que também o conheceu bem no Henri IV, e é um pouco seu patrono, encontra-se por acaso no gabinete onde conversamos. Fala-se de Febvre, Chassigneux me diz: "talvez seja uma vantagem tê-lo contra você. Ele indispõe a assembléia por seu egocentrismo. Após a eleição de Piganiol (que ele havia apresentado) saí com o eleito e lhe dizia: estou curioso de saber como o senhor compreende a história: estou suficientemente instruído com a maneira como Febvre a compreende." Roques acrescenta: "Febvre apresentou Gabriel, depois Piganiol. Ele acreditou que os fez eleger. Na realidade, o Collège tinha seu assento pronto.” Foi sobretudo Pelliot quem empurrou Chassigneux.

Faltava ver sobretudo os cientistas. Eles são uma dezena sobre trinta-trinta e dois professores do Collège, ou seja, sete eliminando-se Piéron, Leriche e Joliot (ver acima).

Em 21 de janeiro, tomo minha coragem com as duas mãos e pergunto ao zelador onde fica o laboratório de Fallot, que escolhi um pouco ao acaso. Paul 44 Fallot, professor de geologia mediterrânea. Subo dois andares num dos edifícios que enquadram a praça, rua Saint Jacques. Entro numa espécie de museu, grandes salas claras, vitrines. Uma jovem, a quem digo meu nome, vai e revém pedindo meu cartão. Introduzido, encontro-me em presença de um tipo que parece um oficial de cavalaria em traje civil, empertigado, com ar aborrecido. Ele se desculpa por não ter-me recebido imediatamente. Explico-lhe que quis esperar que Mauss fosse atingido pelo limite de idade... Ele faz uma careta desagradável, um gesto de negação como para dizer que esse escrúpulo era absurdo. Seria ele antisemita? Eu o entretenho longamente com meus trabalhos. Isso parece interessálo. De resto, eu teria essa impressão freqüentemente com os cientistas. Isso se prolonga por quase uma hora. Ele me reconduz, e à soleira da porta, enquanto eu lhe falava de Strasbourg, das dificuldades que nós tivemos por vezes com os alsacianos, diz de um jeito áspero: "Não deve surpreender. A Terceira República não fez senão bobagens...." Um pouco mais tarde soube por Barrabé, genro de Bouglé, professor de geologia na Sorbonne, que esse Fallot é reacionário, Action française, que foi conduzido ao Comité des Forges por pessoas da grande indústria na África do Norte.

Saindo de lá, vou a um outro prédio, em casa de Fauré-Frémiet, professor de embriogenia comparada. Descendente, como seu nome o indica, ao mesmo tempo do músico e do escultor. Muito amável, cortês, atencioso, de espírito aber- 
to, todo cumprimentos e amabilidade. Eu o havia já visto em casa do Reitor, e numa sessão do Centre de synthèse onde ele falava ao mesmo tempo que André Mayer. Conversamos sobre uma porção de coisas, esquecendo a hora (saio às quinze para uma). Ele me pediu que lhe desse minha Topographie légendaire. Parece bastante informado de muitas questões literárias e históricas. Muito diletante. É parente de Fauconnet. Alguém que poderia votar em mim, se bem que evidentemente se reserve.

Charles Dufraisse, professor de química orgânica. Sobre ele também ignoro tudo. Mais tarde Gabriel me dirá: "é um farmacêutico... E mais, anti-semita. Durante alguns dias, colocou um aviso no seu laboratório: entrada permitida somente aos arianos...." Um sujeito bastante pesado, cabelos brilhantes colados ao crânio e bem aparados. Olhos vazios, um olhar estúpido. Ele me encara como se eu fosse um objeto inerte, e visivelmente tudo o que lhe digo o aturde um pouco. Um verdadeiro "bruto cientista." Apesar de tudo, ele me parece grato pela minha conferência. Talvez esteja ao mesmo tempo envaidecido por eu me ter saído mal, e satisfeito de que tenha acabado. Evidentemente deve me considerar como um fenômeno.

Um literato, para mudar: Pierre Lacau, professor de egiptologia. Foi nomeado há um ou dois anos, contra um colega de Strasbourg, Montet. Escolha talvez injusta. É que Montet fez escavações sensacionais: em Biblos, onde encontrou um templo e talvez uma cidade. Sarcófagos, uma inscrição fenícia que parece a mais antiga de que se tem conhecimento, e em seguida em Tanis. Montet tem mau caráter. É um reacionário consumado. Em Ceyrat, perto de Clermont, vi-o há dois anos, era claramente colaboracionista e antiinglês (é verdade que sua mulher é egípcia). Mas creio que é um nababo. Lacau é um ancião, muito banal. Passou dezesseis anos no Egito. Mas não tirou muita coisa dessa longa permanência. Membro do Institut, e muito bem pensante. Grenier, que foi encontrar antes de entrar, me apresenta a ele. Ele está muito longe daquilo que faço. Falamos do Egito, do filho de Foucart, que conheci lá, que teve uma existência muito romântica e aventureira [...] O que mais falta ao senhor Lacau é seguramente essa fantasia divertida e esse temperamento ardente.

Mais um que está perto da aposentadoria (três anos mais que eu). É Jacques Duclaux, professor de biologia geral. Creio que é seu último ano. É filho do Duclaux do caso Dreyfus, que era, parece, um verdadeiro erudito. Eu ignorava, mas depois soube que ele é protestante. O edifício da biologia geral é um velho casebre todo arruinado, que se ergue isolado atrás do Collège, no espaço vazio na orla da rua Saint Jacques, esmagado pela alta massa do liceu Louis le Grand, como que enterrado numa trincheira onde se revolve a terra, onde há passarelas de madeira, buracos no solo. Trabalhos de pedreiro e de terraplanagem em andamen- 
to, incertos, esboçados. Velhas paliçadas, grades vetustas, pedaços de jardim, um aspecto de fazenda abandonada. Certamente o que há de mais velho aqui. Talvez seja ali que Claude Bernard trabalhou.

Duclaux não tem ar envelhecido. É vivo, sorri; uma afetação de ironia; um pouco de amargura entretanto. De blusa branca. Diz logo que deve ter me encontrado outrora no Cercle du Tour du Monde (Émile Kahn). Deve me conhecer muito bem. Conversação um pouco sôfrega, sem lacuna, ofegante. A psicologia coletiva. Sim. Mas existem trabalhos que façam conhecer a natureza moral deste ou daquele grupo social? Menciono o estudo de Hertz sobre a criminalidade dos Judeus na Polônia. Ah, sim! Isso é interessante. Mas passamos muito depressa sobre diversas observações descosidas. Ele diz, para concluir, que quando uma cátedra fundamental está vaga, se existe alguém para representá-la, a tendência é mantê-la. "O senhor tem muita razão em se apresentar." Ele me reconduz até a grade. "Todo este edifício vai desaparecer. Vai haver aqui um belo laboratório. Mas eu não estarei mais aqui.’[...]

Não vamos tão depressa. Toda esta campanha para o Collège prossegue num período em que os acontecimentos públicos, e os acontecimentos privados em ligação com os acontecimentos públicos, sucedem-se num ritmo por vezes precipitado. Certamente, nada disso penetrava, ou não muito, nas minhas conversas com as pessoas. No entanto, não deixa de ser interessante notar que no início de novembro de 1942 os americanos ocuparam a África do Norte, que os sucessos dos russos (Stalingrado, etc.) atropelam os meses de novembro e dezembro, continuam durante janeiro e fevereiro de 1943 (tomada de Rostov em 14 de fevereiro, etc). Período de sobressaltos e grandes esperanças.

Em 22 de janeiro de 1943, o filho da senhora Psichari (neta de Renan), escrevia a Pierre: "Recebemos ontem um comunicado de Oran. É assustador. Meu irmão está morto, e nós não nos consolaremos jamais de que não tenha sido pela França." Esse irmão, Michel, comandava um dos submarinos que se opuseram aos americanos, em Oran, e foram afundados. Um outro filho da senhora Psichari é méhariste ${ }^{4}$ no exército gaullista. Em $1^{\circ}$ de fevereiro, eu estava com minha mulher na escola Massillon, cais de Célestins, onde era celebrada uma missa em intenção do segundo-tenente da marinha Michel Revault d'Allonnes. Os Febvre estavam assistindo. Troquei algumas palavras com a sra. Febvre, mas partimos logo em seguida, sem ver Febvre que estava retido atrás pela multidão. Ele havia me enviado quinze dias antes um livro que acabava de publicar sobre: a religião de Rabelais, a corrente irreligiosa do século XVI (coleção: L'évolution de l'humanité), com esta dedicatória: "À Madame H[albwachs], ao meu velho companheiro Maurice H[albwachs], este Rabelais que não ri....” Eu o havia lido e, ao encontrar a sra. Febvre, debaixo de uma chuva cerrada, disse-lhe rapidamente 
que passaria um dia para agradecer a seu marido, que seu livro me havia feito passar alguns bons momentos. De fato a primeira parte traçava um quadro vivo das polêmicas do tempo, em versos latinos em que os eruditos procuraram traços de julgamentos severos sobre a atitude religiosa de Rabelais. Mas por outro lado me parecia que Febvre arrombava portas abertas, esforçando-se por demonstrar que Rabelais não era um anticlerical como aqueles do século XIX, que estudava seu autor sob um ângulo bem estreito, que a segunda parte estava estragada por um lirismo um pouco deslocado, que os defeitos de Febvre (descosido, sôfrego, egocêntrico) estragavam bastante o conjunto. Meu amigo Roussel tinha um julgamento ainda mais severo a respeito.

Em meados de fevereiro, soube por Piéron que havia sido decidido deliberar sobre a criação de uma cátedra para a sucessão de Mauss, e que a votação iria ocorrer em breve, sem dúvida em meados de março. Soube também que havia dois outros candidatos: Renaudet, a história do humanismo, e Gouhier, sem dúvida: a história das idéias no século XVI, e que um e outro haviam começado suas visitas.

Renaudet, professor de história moderna na Sorbonne, é três anos mais novo que eu. Gostei muito do livro que ele publicou no ano passado sobre Maquiavel. Está também na École des hautes études. Normalista. Excelente historiador. Encontrei-o em casa dos Nitti (sua mulher é italiana), e tive ocasião, por duas vezes, de conversar um pouco longamente com ele. Claramente de esquerda e muito resistente. Caráter singular, apaixonado, atormentado. Uma mistura de orgulho (muito legítimo) e de modéstia um pouco doentia. Timidez simpática de alguém que tem consciência de seu mérito, mas tem horror do blefe.

Gouhier, substituto há um ano de Rivaud na Sorbonne, onde leciona história da filosofia. Trabalhou de início com Malebranche. Em seguida publicou três grossos volumes sobre a juventude de Auguste Comte: biografia alentada, com muita erudição, e também um certo talento literário. Havia publicado recentemente na N.R.F. uma vida de Auguste Comte que desagradou muito minha irmã Jeanne e meu cunhado Michel Alexandre. Eles desancaram os Libres propos, tratando o autor de Basile... O que me pareceu excessivo. Entretanto, sem dúvida, em todas essas obras, há muito clericalismo latente. Gouhier me era, porém, simpático. Bem antes de ter sido designado para substituir Bréhier, falei dele a meus colegas filósofos, entre os quais ele tinha adversários, e isso sobretudo, o que é curioso, entre os catolizantes: Laporte e Bréhier. Até lhe escrevi, para lhe dizer que queria vê-lo na Sorbonne. Como nossos cursos acontecem nas mesmas horas, nos víamos toda semana. Foi ele quem me colocou em contato com Aubier, e propôs fazer uma edição do Contrato social. Foi no congresso de filosofia de Praga, em torno de 1935, que o vi pela primeira vez, no hotel, com 
meu sogro. Havíamos nos cumprimentado. Meu sentimento era que, temendo ser devolvido à Universidade de Lille, no caso de Rivaud retornar, ele pensava que minha idade seria para mim um obstáculo, e queria tentar a sorte para ficar em Paris. Com 43 anos, uma obra que em suma fazia volume, porém oca, ele me parecia menos temível que Renaudet. Eu me dizia de resto que a divisão dos votos que me eram opostos poderia me servir. Entretanto meu colega Le Senne, o único que informei de minha candidatura, me telefonou naquele momento dizendo que Gouhier se agitava muito, e que era preciso temer a influência de Gilson que ele acreditava, é verdade, todo-poderoso no Collège.

Fui ver Maurice de Broglie, professor de física geral e experimental. Aristocratas-eruditos, os de Broglie têm uma fisionomia original entre os físicos. Representam a física de direita: pois há uma física de direita e uma de esquerda... Abordagem muito cortês, mas fria, reservada: uma geladeira. Apenas descerra os dentes. Eu pensava que o de Broglie do Collège era Louis, aquele da mecânica ondulatória, que resolveu à sua maneira a antinomia onda-corpúsculo e que defendia o indeterminismo. Fiz alusão a um artigo seu que li recentemente. Desta vez, Maurice descerra os dentes: "é meu irmão." Parece interessado pelo que lhe digo de Minkovski, que encontrei outrora em Göttingen. E fala num tom de vanglória de Pierre Weiss, cujo nome pronunciei.

48 Ao sair, na rua des Écoles, encontro Piéron. Ele me comunica que houve uma reunião na qual foi proposto que se fizesse primeiro (para a cátedra a ser criada) uma votação privada, não oficial, de modo a obter maioria. Na sessão oficial, votar-se-ia em bloco por aquele que tivesse assim sido designado. Mas Gilson se opôs, e foi decidido nada mudar do procedimento ordinário. É lamentável, pensa Piéron, porque isso torna mais aleatório o bloqueio dos votos Renaudet-Halbwachs sobre um de nós dois. As pessoas podem temer que no segundo turno haja apenas uma fraca maioria, e se Gouhier vem na frente do primeiro turno, pode acabar ganhando no segundo. Piéron coloca então a questão: quem apresentará a psicologia coletiva? "Digo-lhe": o que eu ia lhe perguntar. "Ele hesita: "por que não Tonnelat? Você está mais informado do que ele sobre o que eu fiz." Então, logo a seguir, aceita. Bom sinal, pois se tivesse pensado que tenho poucas chances, teria se esquivado. Pede-me que redija um papel no qual se inspirará. Três ou quatro páginas? Mais, cinco ou seis. Um pensum em perspectiva...

Tonnelat, que encontro, diz que recebeu uma notícia: títulos e trabalhos de Gouhier. Diz ali que continuará o que tem feito até agora, biografias de filósofos...

Gabriel vem me ver. Eu the havia escrito desde outubro, creio, comunicando-lhe que seria candidato. Não me respondeu. Mas há três semanas, chegando 
de Bar sur Aube onde vive com sua mãe e sua irmã, passou por minha casa, e conversamos sobre diversas coisas. Algumas palavras sobre o Collège, sem insistir, como se fosse um projeto muito distante e pouco real. Albert Gabriel foi nomeado há dois anos, no reinado de Carcopino, professor de história das artes do Oriente muçulmano. Candidatura preparada de longa data. Febvre o apoiou muito. Mas eu o havia recomendado de modo muito [palavra riscada] caloroso a Piéron, que se declarou a seu favor. Ele me era muito grato por isso. Velho amigo de Strasbourg. Muito íntimo. Longas jornadas de domingo passadas juntos. Quando ele dirigia o Institut archéologique d' Istambul, me fez ir até lá. Viajei com ele e fiquei quinze dias no seu Institut. Isso por volta de 1937. Em 1939, quando de minha viagem a Beirute, fui até a casa dele na ida e na volta. Portanto, laços de amizade muito estreitos. Mas como é também grande amigo dos Febvre, eu não sabia o que pensar. Ele entra e me diz: "sou eu, professor do Collège, quem vem lhe fazer a visita que o senhor deveria me fazer." Acrescenta: "pode contar com meu voto." Fico sabendo por ele que Gouhier move céus e terra. "É um padreco." Casado com uma judia convertida, aparentada com o banco Lazare, muito relacionada, dispõe de grandes influências. Somos sobrecarregados de recomendações. Mas ele faz mais... Conselhos: é preciso fazer falar aos cientistas, antes de vê-los. Por exemplo, Leriche se dá muito bem com Lacassagne. Prevenir também Courrier, e Oehmichen: um e outro muito abertos, muito inteligentes. Rever Piganiol... Nada a fazer com Febvre. Jantou com ele, na véspera. Está muito engajado com Renaudet. Mas a grande ofensiva vem dos clericais. Diz-me para vir no final de seu curso, sábado à tarde. Iremos juntos ver Leriche, que termina o seu um pouco mais tarde.

Vou ao encontro marcado. Mas Gabriel diz, quando o encontro em seu escritório: "espero o seu concorrente, Renaudet. Impossível acompanhá-lo". E me pergunta, com um ar que me parece perplexo: "Será que há algo de novo?" Vou portanto esperar Leriche. Uma multidão sai de seu curso. Ele me vê. "Olá, H[albwachs]", e me chama de lado, entre duas portas. Diz que falará a Lacassagne. Acrescenta: "Prometo-lhe meu voto para o primeiro turno. Mas no segundo, combinamos fazer um bloco sobre o que tiver a maioria no primeiro, para forçar o Ministro." Respondo: "Está bem. Mas é o primeiro turno que importa, agradeço sua promessa."

[Nota no alto da página: Ao regressar nessa tarde, 27 de fevereiro, soube que Francis, em Aix, foi atropelado por um automóvel, perdeu a consciência, mas acabou apenas com uma ferida superficial. Sua cabeça afundou o farol do automóvel. Ele passou ao lado da catástrofe...]

Robert Courrier, professor de morfologia experimental e endocrinologia, membro da Academia de medicina. Um homem relativamente jovem, um pouco 
sangüíneo, olhar intenso, traços móveis, animados, expressivos, uma inteligência bem adaptada à vida, com limites que são os de uma espécie de inteligência, portanto fixados pela natureza, mas, no quadro, de primeira ordem. Ele se esforça para compreender plenamente o que lhe exponho, e me dá a ocasião de passar em revista todas as partes de minha atividade, todos meus objetos de interesse. O que lhe digo da memória coletiva, dos quadros sociais do pensamento, do sonho... A propósito da África do Norte, diz que há muito tempo viveu na Argélia, que teria desejado que alguém fizesse um estudo psicológico dos Mzabitas. Interessado pelo que há de concreto em nossas pesquisas. Conversa que se prolonga por uma hora. Pergunta se há outros sociólogos. Saio, com a idéia de que ele hesita ainda um pouco, mas que no fim, se Piéron apresentar bem a coisa (ele parece dar importância ao que me "relata"), votará em mim. Alguns dias depois, soube que obrigado a deixar Paris, ele não iria assistir à sessão. Oehminchen estará ausente também: está instalado longe de Paris, e só retornará em junho. É professor de aerolocomoção mecânica e biológica. Recebi dele uma carta muito amável, endereçada... à Faculdade de ciências (por causa de meus títulos e trabalhos)...

No dia seguinte, tenho a idéia de ir até a casa de Febvre, para me desobrigar da promessa feita à sua mulher e agradecer-lhe por seu livro. Ele me explica em termos embaraçados que, se Renaudet se apresenta, é porque havia sabido 50 que Le Bras era candidato, e ainda por uma cátedra de sociologia. Então, calculando que diante de tal disputa pela sucessão de Mauss, minha proposição estava ameaçada, ele não teve escrúpulo em se posicionar. Mas Le Bras não é candidato. Então, como Renaudet começou suas visitas, ele continua... Ele é candidato sem sê-lo, embora sendo... tudo isso está evidente. Febvre acrescenta que tendo falado muito ultimamente (o leão cansado da carnificina), aconselhou Renaudet a ir ver Mario Roques e pedir-lhe que seja seu relator (o que me parece barroco), sem jogo de palavras, pois o tal Roques é muito anti-Febvre e me deixou saber que não votará em Renaudet). Isso seria uma manobra hábil se Roques não estivesse, quase, comprometido comigo, o que Febvre ignora, a menos que tenha tido alguma notícia disso, e não me diz isso senão para que eu descubra minhas baterias. A conversa continua sobre o século XVI, Rabelais, Erasmo, Calvino, segundo ele um grande escritor. Interessante e vivo e dando a impressão de estar bem no seu elemento. Digo-lhe, ao partir, que traduzirei à minha mulher os versos latinos reproduzidos no seu livro. Sorrimos, um e outro.

No dia seguinte, indo ver meu amigo Roussel, o helenista, soube por ele que no Institut falou-se de minha candidatura. Objeta-se à minha idade: Roques em particular, ao menos Roussel, sem ser muito afirmativo, encontrou-o vago, evasivo. Telefono a Roques. Ele me diz isto: "há quinze dias me parecia sempre mais provável que Gouhier ganharia. Habilmente empurrado por Gilson e os filóso- 
fos, sustentados por Hazard, por outros mais... Mas isso mudou, e posso dizer quando, na última sexta-feira (26 de fevereiro, véspera de minha última entrevista com Leriche: haveria uma reunião do Collège nesse dia). O vento mudou e a seu favor. As pessoas refletiram, e estão em dúvida sobre o real valor de Gouhier. Mesmo Hazard me pareceu abalado. Acrescento que alguns (sem dúvida Hazard) me solicitaram para ser o relator, para a proposição de Gouhier...." Tive um sobressalto, invisível porém ao telefone. Mas espero: "sim, como, da última vez, sustentei Lavelle contra os filósofos, deram-me a oportunidade de restabelecer o equilíbrio, expondo desta vez os títulos de alguém que está do lado deles”... Meu Deus, como tudo isso é complicado, e como este terreno é movediço! Não seria que Roques, sentindo o vento, teria sido levado se não a me abandonar, ao menos a fazer um gesto favorável ao outro partido? Seu argumento não se sustenta. Ele retoma, num tom de homem honesto indignado, que afasta uma proposição duvidosa: "Mas eu disse: não, não e não. Não quero apresentar um candidato, agora que me decidi a votar em outro." Agradeço-lhe o que acaba de me dizer, e aqui termina nossa conversa pelo telefone. Antes, contando meus votos seguros, 9 ou 10, ele havia notado que arriscávamos chegar os três ao empate. Então, é preciso agir sobre os cientistas. Eles decidirão.

Em 27 de fevereiro Piéron me escreveu dizendo que a eleição para as cátedras vagas do Collège estava marcada para domingo, 14 de março (em 11 de março, terei 66 anos...). "Será preciso que eu tome a iniciativa da proposição que te diz respeito, pois, nesta fase preparatória não há candidatura, e são os membros da Assembléia que devem introduzir esses pedidos." Mas o que mais retém minha atenção são as duas linhas que se seguem: "Massignon e Pelliot estão muito decididos a sustentá-lo. Mas creio que a maioria está muito indecisa." E, em seguida: "Temo muito a ação muito decidida de Gilson em favor de Gouhier, e a divisão que a proposição de Febvre arrisca de suscitar. De fato está combinado que os votos serão descarregados no segundo turno, na candidatura que esteja na frente no primeiro." O que retenho sobretudo dessa carta é que Pelliot e Massignon passaram para o meu lado. Eu pensava que Pelliot votaria contra mim. Quanto a Massignon, me parecia sempre inalcançável. Contava aqueles que me haviam prometido voto: Piéron, Tonnelat, Gabriel, Leriche, Grenier, Roques, aos quais eu acrescentava Joliot, Chassigneux, talvez Faral. Com isso eram nove. Com Pelliot e Massignon, onze. E Pelliot devia ter influência. Com dois ou três cientistas a mais, eu teria chance de ganhar.

No dia seguinte, Tonnelat me confirmava pelo telefone que Massignon e Pelliot estariam comigo. Como partilhei com eles minhas inquietudes sobre o procedimento adotado na votação, ele me respondeu: "não se preocupe. Estou agora muito otimista. Parece-me que você pode esperar o resultado de espírito 
tranqüilo." Alguma coisa devia ter-se passado. Ele disse, de fato, quando fui vêlo no dia seguinte, que Pelliot havia intervindo muito claramente a meu favor, "em primeiro lugar porque me estimava muito, e depois porque devido mesmo à minha idade, tratava-se de me dar ainda alguns anos de ensino: consideração para com a pessoa". Quanto a Gouhier, era preciso considerar que nós o teríamos por vinte e cinco anos, e que não se sabia o que produziria, nem se aconteceria alguma coisa. Essas declarações feitas com convicção deram resultado. Mazon chamou Tonnelat de lado e lhe disse: "não acha que seria conveniente ter um historiador das idéias, que reforçaria o grupo dos literatos?" Ao que Tonnelat respondeu que Gouhier lhe parecia sobretudo um fingido e, além do mais, era colaboracionista... Ao que Mazon, muito intrigado, lhe teria perguntado sobre o que ele se apoiava para... Não sei o que Tonnelat the respondeu. Talvez exagerasse, se bem que Gouhier seja de fato pouco "resistente" e pouco otimista. Mas o argumento era ad hominem, pois Mazon, pelas razões que eu disse, é muito germanófobo. ele conversou também com Gilson e o achou , em suma, muito mole, muito menos combativo do que me escrevia Piéron.

Lacassagne, professor de radiobiologia experimental, diretor do Laboratoire de Radiophysiologie de l'Institut du Radium, rua d'Ulm 26. É lá que vou encontrá-lo. É um lyonês, bastante jovem. Conversação muito variada. Interessa-se por sociologia, e a conhece um pouco porque seu pai, médico legista em Lyon, publicou livros sobre tatuagem, etc. Sociologia antropológica, sobre a fronteira da medicina. Minhas pesquisas sobre as relações entre os sexos, o nascimento... é uma oportunidade de discutir alguns pontos a respeito da sexualidade, etc. Mas a propósito de Lyon e dos lyoneses, ele descobre ser amigo de Montet e de sua família, me pergunta onde está agora Jacques, e Gustave, e Marianne. Conheceu bem a senhora Montet, que fazia radioterapia. Montet, depois da morte de sua mulher, deu ao Institut, não sei em que condições, todo o rádio que ela possuía. Falamos também de Leriche. As amizades lyonesas... Tive também uma vaga impressão de que ele é de esquerda. Piéron me dirá, alguns dias mais tarde, que ele está do meu lado.

A 6 de março, na Societé de psychologie, Piéron me leva ao seu gabinete no Laboratório, e lhe passo meu papel. Ele diz que escreveu a Faral para lhe expor, em nome de vários, que não aceitam o procedimento de dois turnos, simplesmente, que é preciso ou interromper após o primeiro turno para fazer uma sessão privada na qual se votaria até que se obtivesse uma maioria absoluta, ou então voltar ao procedimento normal. Em seu relatório ele lembrará que Tarde ocupou uma cátedra de psicologia social, e que há uma tradição a continuar. Além disso, avalia que "isso não seria mau."

Últimas visitas. Jean Przyluski, professor de história e filologia indochine- 
sas. Sofre (desde uma longa estada no Extremo-Oriente) de uma surdez total. Tonnelat me disse que é impossível prever o que ele fará, tanto vive solitário. Eu o abordo, muito perplexo, à saída de seu curso. Mas, desde que viu minha carta, declara: "Não precisava se incomodar. Votarei no senhor. Sou aluno de Mauss, e hostil às transformações propostas. É preciso manter a sociologia." Fala com volubilidade, sem esperar uma resposta. Grito com todas as minhas forças, congestionado. Ele me olha com um sorriso triste. Penso que não entendeu nada. Parto, muito reconfortado. Mas, não sei por que (dizem que está brigado com Faral), ele não virá à sessão.

Visito Faral, o administrador. Muito fechado. Jeito aborrecido, embaraçado. Fala mal da sociologia dos primitivos, a de Mauss. "Eu sei que a sua é muito diferente." Fala de questões gerais. Muito malévolo em relação aos judeus, aos quais censura a indiscrição. Descontente além disso do ministério, que o substituiu por um inspetor-geral na presidência da banca de agregação de gramática. Quanto á eleição para o Collège: "Não sei nada sobre como isso vai acabar." Digo-lhe que não se pode me censurar por me apoiar nos Strasbourguenses. Ele pergunta, curiosamente, quais pessoas de Strasbourg votarão em mim. Deixa-me a impressão de um administrador pusilânime, embaraçado, que não quer dizer nada. Vermelho de descontentamento, contra os outros e talvez contra si mesmo.

$\mathrm{Na}$ véspera da votação, somente em 13 de março, consigo ver Maspéro, que sai de uma enfermidade e só nesse dia retomou seus cursos. Professor de língua e literatura chinesas. Um homem pequeno, magro, seco, mumificado. Me deixa falar longamente, e ouve com grande atenção. Não muito de acordo com Granet, mas fala dele com estima e pesar. Erudito modesto, muito menos acadêmico do que eu esperava, espírito aberto. Diz como vê a evolução moderna da China, onde esteve por longo tempo. Lembro-me de que Clodius Maître, outrora, dizia de sua surpresa, quando pôde entrar na intimidade dos grandes sinólogos, de descobrir uma riqueza de idéias filosóficas e uma visão larga sobre o mundo e a história que contrastavam com sua erudição tão especial.

Noto ainda que Grenier, encontrado muitas vezes, não cessou de me encorajar. "Seus amigos trabalham pelo senhor, dizia ele." Foi ele quem me disse que Piganiol votaria em mim.

Chegamos ao 14 de março, dia da votação. Espera enervante até as quinze para as 5. Eu sabia que a reunião deveria começar por volta de 2 horas [nota à margem: Leio o Rabelais]. Às 4 e meia vamos tomar chá na cozinha. Nesse momento, toca o telefone. A voz de Piéron, trepidante, triunfante. "Bom! Aí está!" Em 30 votantes: no primeiro turno, 14 votos em mim, 10 em Gouhier, 6 em Renaudet. No segundo turno, 17 votos em mim, 12 em Gouhier, 1 em Renaudet. Siegfried falou contra a sociologia e votou com Gilson. Gabriel telefona logo de- 
pois, em seguida Massignon. Ambos dizem que Piéron, designado por sorteio para falar primeiro, esteve excelente. Febvre, brilhante, mas de um lirismo e de um personalismo extraordinário. Gilson, muito mole, Febvre me telefona em torno das 6 h, bem lamurioso, bem aborrecido, com uma voz de alcoólatra que treme um pouco. Ele chora no meu ombro. Lamenta que Renaudet não tenha tido mais votos. "Ele é muito tímido. As visitas o aborreciam." Acabou-se para ele. Tem três anos mais que você, e não se apresentará mais (as oportunidades, de fato, não aparecem a toda hora). Pede-me que felicite minha mulher... Digo-lhe que lhe agradeço, e "até logo"... No fundo, é ele o grande vencido nesta batalha.

Segundo o que soube dos diversos lados (e segundo as garantias que alguns me deram) eis aqui os que devem ter votado em mim: Piéron, Tonnelat, Leriche, Gabriel, Piganiol, Grenier, Pelliot, Massignon, Maspero, Joliot, Lacassagne, Roques (todos eles, ou seja, 12, certamente), Fauré-Frémiet, Coornaert, Robert (?) Chassigneux, Faral (?) ou seja, 17.

Votaram contra mim [duas palavras riscadas] a favor de Gouhier: Gilson, Lavelle, Baruzzi, Mazon, Hazard, Siegfried, Lacau (?), Fallot, Defraisse, de Broglie, Duclaux (?), Valéry (?), ou seja, 12.

Febvre deve ser sido o único a votar em Renaudet no segundo turno.

Piéron acredita que Faral votou contra mim, em Gouhier, por razões admi54 nistrativas, temendo que minha eleição trouxesse dificuldades junto ao ministério. Isso me surpreenderia. Impossível desvendar esse mistério.

Em suma, tive contra mim os filósofos católicos, a Academia francesa, os clericais, o único representante (grande burguês) da Academie des sciences morales et politiques (da qual sou correspondente), os cientistas reacionários.

Tive a meu favor quase todos os lingüistas, os eruditos especialistas das diversas civilizações (exceto Mazon), os historiadores, os cientistas avançados, sobretudo quatro biologistas (ou médicos). Faltaram-me dois ausentes, Przyluski e Wallon (que era do meu lado, mas cujo curso foi suspenso), e também (segundo Piéron) Courrier: ou seja, três ausentes.

Eu não havia visitado Valéry: Tonnelat havia dito, por engano, que ele não tinha direito de voto (prorrogado por um ano).

(5 biologistas: Leriche, Lacassagane, Fauré-Frémiet, Courrier, Piéron faltou apenas Duclaux, que deve ter seguido Siegfried).

Em resumo, filosofia metafísica e religiosa, literatura pura, ciência dos rapaces, contra a história sociológica, psicologia científica, lingüística, e biologia. Tudo isso era natural.

Piganiol soube que Valéry, sentado ao seu lado, votou em mim.[...]

5 de julho: Três meses e meio se passaram depois da votação para as cátedras. Soube em abril que ela foi transmitida ao ministério e retida pelo Gabinete 
(Chefe de gabinete: Georgin, ex-pacifista). Em junho, vejo Siegfried na reunião da Pesquisa científica. Ele me diz saber por uma pessoa bem situada, que no que me diz respeito não há objeção. Mas soube por Tonnelat isto: no mesmo dia da psicologia coletiva, o Collège propôs outras duas cátedras: uma (em substituição à história da arte, cujo titular, Focillon, acabava de morrer nos Estados-Unidos, privado de sua nacionalidade e demitido), cátedra de latim, para Ernout; a outra, para um cientista que está no sul, num laboratório dos Pirineus. Ora, Préchac, diretor do ensino superior há pouco tempo, é inimigo mortal de Ernout, que o impediu de ser nomeado para a Sorbonne. Assim se explica o atraso na declaração das vagas. De resto, há quinze dias, soube por Roques que telefonaram a Faral para solicitar as proposições. "Eu as enviei a vocês faz três meses - Sim. Mas nós as perdemos." 9 de janeiro de 1944. Donteville vem me ver e diz que há três dias Bonnafous, ministro do Abastecimento, se demitiu, e dizem que ele me substituirá na Sorbonne. Em 10 de janeiro Piéron me telefona. A criação suspensa de três cátedras é assinada: o decreto vai sair no Officiel. Em 22 de janeiro, Faral me diz por telefone que o decreto saiu naquele mesmo dia no Officiel (é segunda-feira, 10 de janeiro, à tarde meus sogros foram assassinados. Eu estava em Lyon).

Minha nomeação, a partir de $1^{\circ}$ de abril, foi assinada em 15 de maio. Soube alguns dias mais tarde, voltando de Mocquebaril (Loir et Cher). Parece, segundo Tonnelat, que Faral havia retornado ao ministério, e que somente em relação a mim (e não aos dois outros) Bonnard fez algumas objeções, perguntando a Faral se minha nomeação não provocaria protestos... [nota à margem: Na data de 9 de janeiro, Geneviève escreve de Lyon: "Sonhei esta noite que, Papai recebia sua nomeação ao Collège de France gravada numa argola de guardanapo, e ele estava muito contente"]. 


\section{NOTAS}

${ }^{1}$ Texto publicado originalmente na Revue d'Histoire des Sciences Humaines. Villeneuve d'Ascq, Presses Universitaires du Septentrion, 1999, n.1: 189-228. O texto original contém notas explicativas de Laurent Mucchielli e Jacqueline Pluet-Despatin. Tradução de Teresa Malatian.

${ }^{2}$ No original, résistant, ligado à Resistência contra a ocupação alemã na França.

${ }^{3}$ Natural de Auvergne.

${ }^{4}$ No exército de De Gaulle em atividade no norte da África, soldado montado em dromedário, que se deslocava pelo deserto.

${ }^{5}$ No original, baroque.

Artigo recebido em 06/2000. Aprovado em 11/2000. 